\title{
Water Vapor Fluxes over the Intra-Americas Sea: Seasonal and Interannual Variability and Associations with Rainfall
}

\author{
Alberto M. Mestas-NuñeZ \\ Cooperative Institute for Marine and Atmospheric Studies, University of Miami, Miami, Florida \\ DAVID B. ENFIELD \\ NOAA/Atlantic Oceanographic and Meteorological Laboratory, Miami, Florida \\ CHIDONG ZHANG \\ Rosenstiel School of Marine and Atmospheric Science, University of Miami, Miami, Florida
}

(Manuscript received 6 December 2005, in final form 27 July 2006)

\begin{abstract}
The seasonal and interannual variability of moisture transports over the Intra-Americas Sea (including the Gulf of Mexico and the Caribbean Sea) is evaluated using the NCEP-NCAR global reanalysis. The seasonal variability of these moisture transports is consistent with previous studies and shows distinctive winter and summer regimes. Boreal winter moisture is mainly delivered to the central United States from the Pacific with some contribution from the Gulf of Mexico. It is during the boreal summer that the moisture flow over the Intra-Americas Sea is most effective in supplying the water vapor to the central United States via the northern branch of the Caribbean low-level jet. The increase of intensity of this jet during July is associated with an increase in evaporation over the Intra-Americas Sea, consistent with midsummer drought conditions over this region.

During both summer and winter, the interannual variability of the inflow of moisture from the IntraAmericas Sea into central United States is associated with Caribbean low-level jet variability. The source of the varying moisture is mainly the Gulf of Mexico and the North Atlantic area just east of the Bahamas Islands and the sink is precipitation over east-central United States. The main teleconnection pattern for these interannual variations appears to be the Pacific-North American, although in boreal winter ENSO and possibly the North Atlantic Oscillation may also play a role. During boreal summer, associations with ENSO mainly involve the zonal moisture exchange between the Intra-Americas Sea/tropical Atlantic and the tropical Pacific.
\end{abstract}

\section{Introduction}

Mestas-Nuñez et al. (2005) have recently evaluated the uncertainties in estimating moisture flux divergences over the Intra-Americas Sea (IAS; composed of the Gulf of Mexico and the Caribbean Sea) using several datasets, which include sounding observations, the National Centers for Environmental Prediction (NCEP) Eta regional analysis (Black 1994), the NCEPNational Center for Atmospheric Research (NCAR)

Corresponding author address: Alberto Mestas-Nuñez, Texas A\&M University-Corpus Christi, 6300 Ocean Dr., Corpus Christi, TX 78412.

E-mail: alberto.mestas@tamucc.edu global reanalysis (Kalnay et al. 1996; Kistler et al. 2001), and the European Centre for Medium-Range Weather Forecasts (ECMWF) 15-yr global reanalysis (ERA15, Gibson et al. 1997). They examine uncertainties arising from choices of area boundaries, calculation algorithms, spatial and temporal resolutions, as well as a combination of these effects. Their main conclusion is that these uncertainties are smaller than the large annual and interannual variabilities in moisture flux divergence estimated from the NCEP-NCAR reanalysis. The implication is that the NCEP-NCAR reanalysis with its global coverage and long record can be useful for estimating short-term climate variability of the moisture flux divergence over the IAS. This conclusion is consistent with a recent comparison between the

DOI: $10.1175 / J C L I 4096.1$

(C) 2007 American Meteorological Society 
NCEP-NCAR global reanalysis and the NCEP regional reanalysis over North America on seasonal time scales (Mo et al. 2005).

Mestas-Nuñez et al. (2005) also reviewed what is known about the IAS as a source of moisture for U.S. precipitation during the boreal summer based on previous studies. Briefly, there are two main avenues for the warm season moisture supply from the IAS: the southerly Great Plains low-level jet (LLJ) on the east side of the Rocky Mountains and a southerly flow of moisture over a wider region across the Gulf of Mexico coast farther east, punctuated by surges associated with summer frontal passages. During boreal summer (Fig. 3 , bottom), the easterly trade winds carry moisture from the Atlantic into the Caribbean Sea where the flow intensifies forming the Caribbean LLJ (Amador 1998; Amador and Magaña 1999). This jet then splits into two branches, with the northward branch turning northward to cross over the Yucatan Peninsula and connecting with the Great Plains LLJ.

While many studies have investigated the relationship between the Great Plains LLJ and precipitation over the United States, there are no previous studies that look at how the water budget of the IAS varies on interannual time scales, or how this variability is related to SST and precipitation variability in and around the IAS. It is known that on interannual time scales the strength of the Caribbean LLJ varies through ENSO cycles (Mora and Amador 2000). However, how these interannual variations affect the moisture budget above the IAS and its association with precipitation has not been documented.

The main goal of this study is to use the global NCEP-NCAR reanalysis to study the seasonal and interannual variability of the moisture fluxes over the IAS and their relationship with SST and with precipitation. We try to identify the sources and sinks of moisture as well as the climatic patterns behind the interannual variations. For relating the fluxes with precipitation, we do not use precipitation from the global NCEP-NCAR reanalysis because of its questionable quality over many regions including the IAS (MestasNuñez et al. 2005), the central United States (RuizBarradas and Nigam 2005), and over the Atlantic Ocean near Florida (Mo et al. 2005). Furthermore, Mestas-Nuñez et al. (2005) showed that it is not possible to close the water budget over the IAS using only the global NCEP-NCAR reanalysis fields and emphasized the large uncertainties in present estimates of precipitation and evaporation over the region.

The paper is organized as follows. In section 2 we describe the datasets and methods. The seasonal variability of the moisture fluxes and its association with rainfall are discussed in section 3 . The interannual variability, its association with precipitation and sources and sinks of moisture, as well as the mechanisms involved are addressed in section 4 . The paper ends with a summary and conclusions in section 5 and concluding remarks in section 6 .

\section{Datasets and methods}

\section{a. Atmospheric reanalysis}

The main dataset used is the daily NCEP-NCAR global atmospheric reanalysis (sometimes referred to as Reanalysis 1; Kalnay et al. 1996; Kistler et al. 2001) for the period 1960-2003. The NCEP-NCAR global reanalysis is available online from the National Oceanic and Atmospheric Administration (NOAA) and the Cooperative Institute for Research in Environmental Sciences (CIRES) Climate Diagnostic Center (CDC) with 6-hourly (0000, 0600, 1200, and 1800 UTC) temporal resolution as well as condensed daily and monthly averaged versions. For practical reasons we use the smaller daily averaged version of the 6-hourly dataset. However, this decision was taken after verifying that the uncertainties introduced by the loss of temporal resolution were not significant (Mestas-Nuñez et al. 2005).

\section{b. Precipitation}

We use monthly estimates of global precipitation that combine observations with numerical model predictions from the Climate Prediction Center Merged Analysis of Precipitation dataset (CMAP; Xie and Arkin 1997) for the period 1979-2003. The seasonal cycle and anomalies of precipitation were computed using the 1979-2003 period as a base. This period overlaps with the SST and moisture flux datasets described in sections $2 \mathrm{c}$ and $2 \mathrm{~d}$ and is used as the comparison period for this study.

\section{c. Sea surface temperature}

The sea surface temperature dataset used here is the extended version of the global analyses generated by Kaplan et al. (1998) on a $5^{\circ} \times 5^{\circ}$ grid. This dataset is available online from the Lamont-Doherty Earth Observatory Climate Data Library and combines the original 1856-1991 Kaplan et al. dataset with the Reynolds and Smith (1994) optimum interpolation (OI) product after November 1981. The reference climatology for the Kaplan et al. (1998) SST anomalies is the 1951-80 Global Ocean Surface Temperature Atlas (GOSTA; Bottomley et al. 1990) climatology. However, for the 


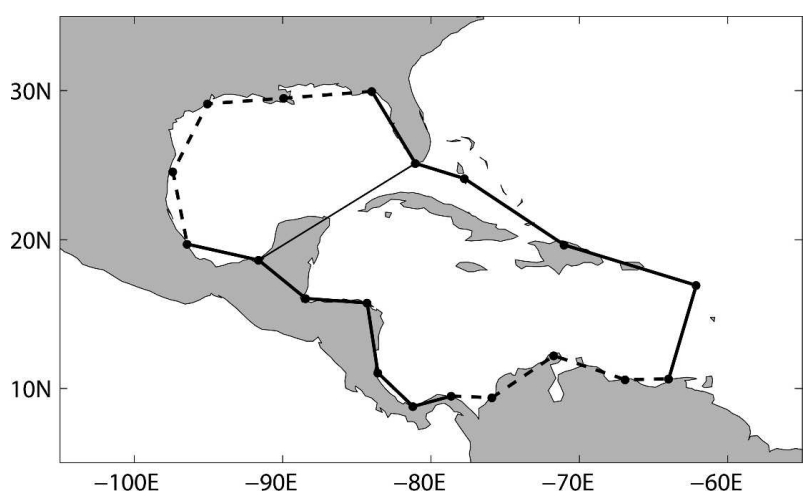

FIG. 1. The polygonal boundary shown with thick solid and dashed lines defines the IAS region for the purposes of this study. The thick solid (dashed) lines indicate the IAS eastern and western (northern and southern) boundary segments. The thin solid line divides the region into two subregions: the Gulf of Mexico to the north and the Caribbean Sea to the south.

comparisons of this study we added the GOSTA climatology back to the Kaplan et al. (1998) anomalies and recomputed the anomalies using the shorter 1979-2003 base period.

\section{d. Moisture fluxes}

The atmospheric moisture flux through a vertical wall that intersects the earth's surface at the curve joining points $a$ and $b$ along a closed curve $\gamma$ is calculated as

$$
\mathrm{F}=\int_{a}^{b}(\mathbf{Q} \cdot \mathbf{n}) d \gamma,
$$

where $\mathbf{n}$ is a unit vector perpendicular to $\gamma$ with outward direction and $\mathbf{Q}$ is the vertically integrated water vapor flux vector given by

$$
\mathbf{Q}=\int_{\text {top }}^{\mathrm{sfc}} q \mathbf{V} \frac{d p}{g},
$$

where $q$ is specific humidity, $\mathbf{V}$ is the vector wind velocity, $p$ is pressure, and $g$ is gravity.

To study how the variability of the moisture fluxes over the IAS affects the surrounding areas, we consider $\gamma$ to enclose the IAS region and divide it into four segments as shown in Fig. 1. The four boundary segments separate the IAS from the Atlantic Ocean (eastern), North America (northern), Central America and the Pacific Ocean (western), and South America (southern). The moisture flux through each of these boundary segments is calculated using (1). The fluxes through the IAS's northern and western boundary segments are, respectively, referred to as "to north" and "to west." The fluxes through the IAS's eastern and southern boundary segments are multiplied times -1 to represent incoming fluxes and are, respectively referred to as "from east" and "from south."

The area average \{\} of the moisture divergence (div Q) in the IAS region can be calculated using Gauss's theorem on the plane as

$$
\{\operatorname{div} \mathbf{Q}\}=\frac{1}{A} \oint_{\gamma}(\mathbf{Q} \cdot \mathbf{n}) d \gamma,
$$

where $A$ is the area enclosed by $\gamma$. Note that while the left-hand side of (3) requires knowing $\mathbf{Q}$ everywhere in the interior, the right-hand side requires only values along the boundary. In this paper, we estimate the IAS moisture divergence from the right-hand side of (3) by taking the sum of the two outgoing fluxes (to north and to west) minus the sum of the two incoming fluxes (from east and from south) and dividing all by $A$. The area-averaged moisture divergence is in turn related to evaporation $(E)$ and precipitation $(P)$ through the simplified water balance equation:

$$
\{\operatorname{div} \mathbf{Q}\}=\{E-P\},
$$

where the local rate of change of water vapor storage, a term that is very small except during severe storms and for short periods of time (Peixoto and Oort 1992), has been neglected.

The long-term mean seasonal cycle anomalies of the fluxes through the four IAS boundary segments and of div $\mathbf{Q}$ were calculated using the 1979-2003 base period, as done with precipitation and SST. The association of these flux anomalies with precipitation and other variables is calculated using temporal correlations. All the temporal correlations presented in this paper are considered significant if they exceed the $95 \%$ confidence level estimated using the method of Davis (1976).

\section{e. Climatic indices}

To investigate the mechanisms behind the associations between the moisture fluxes and rainfall we will use the following climatic indices: Pacific-North American (PNA; Wallace and Gutzler 1981), ENSO (Niño-3 and -3.4), North Atlantic Oscillation index (NAO; Hurrell 1995), tropical North Atlantic index (TNA; Enfield et al. 1999), temperature of the IAS, temperature of the Gulf of Mexico, temperature of the Caribbean Sea, and Western Hemisphere warm pool index (WHWP; Wang and Enfield 2001).

The Niño-3, Niño-3.4, and TNA indices were obtained by area averaging the Kaplan SST anomalies (see section $2 \mathrm{c}$ ) in the following respective rectangular regions: $5^{\circ} \mathrm{S}-5^{\circ} \mathrm{N}, 150^{\circ}-90^{\circ} \mathrm{W} ; 5^{\circ} \mathrm{S}-5^{\circ} \mathrm{N}, 170^{\circ}-120^{\circ} \mathrm{W}$; 
and $5^{\circ}-25^{\circ} \mathrm{N}, 55^{\circ}-15^{\circ} \mathrm{W}$. The temperature of the IAS index was obtained by area averaging the monthly Kaplan SST anomalies at all the grid points inside the IAS polygonal region in Fig. 1. The temperature of the Gulf of Mexico and Caribbean Sea indices were calculated in a similar way but using the grid points inside the respective subregions defined in Fig. 1.

The monthly WHWP (area of the eastern tropical Pacific and tropical Atlantic with SST $>28.5^{\circ} \mathrm{C}$ ) anomaly index was obtained from the Climate Diagnostic Center Web site (www.cdc.noaa.gov) and its base period is 1951-2000. The monthly PNA index was obtained from the Climate Prediction Center Web site (www.cpc.ncep.noaa.gov), its base period is 1950-2000, and it was calculated using the method of Barnston and Livezey (1987).

\section{Seasonal variability}

\section{a. Moisture fluxes}

The seasonal cycles of precipitation, evaporation, and moisture divergence in the IAS show two distinct winter and summer regimes (e.g., Hastenrath 1966; Mestas-Nuñez et al. 2005). Hereafter we refer to the boreal winter (summer) season as composed of the December-March (June-September) calendar months. These 4-month seasons are considered because they describe well the two epochs seen in the seasonal cycle of the IAS moisture divergence. This also allows us to increase the number of monthly samples for the seasonal correlation analysis discussed in the next section.

For each of the four moisture flux time series as well as for the IAS moisture divergence time series, calculated as explained in section $2 \mathrm{~d}$, we estimated the longterm mean seasonal cycles for 1960-2003 and display them in Fig. 2. During boreal winter, the fluxes to the north into the United States and from the south from South America are small and the balance is nearly zonal with the import of moisture from the east plus water vapor added locally in the IAS approximately equaling the flow exported to the west into the Pacific. During boreal summer, on the other hand, the seasonal moisture balance has both zonal and meridional components. The balance is mainly between moisture imported from the east and south and moisture exported to the north and west. During July-August the moisture inflow from the east is about twice as large as the one from the south and it nearly balances the outflow to the Pacific. Although smaller, the local contribution of water vapor represents a source during July due to increased evaporation and a sink during September due to increased rainfall over both the Gulf of Mexico and the Caribbean Sea (Mestas-Nuñez et al. 2005).

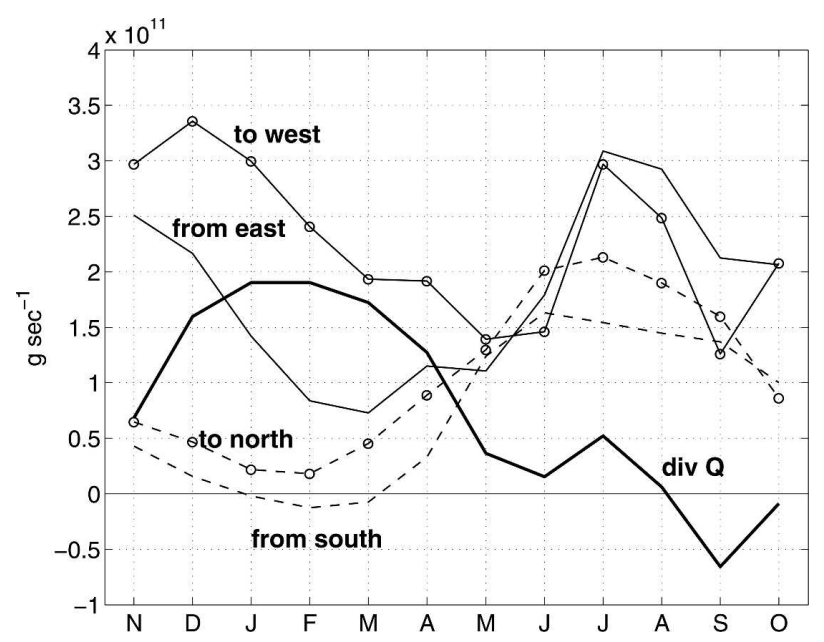

FIG. 2. Long-term mean seasonal cycle of the monthly incoming moisture fluxes from the east (thin solid) and south (thin dashed) and of the outgoing fluxes to the north (dashed with circles) and west (thin solid with circles) through the respective IAS boundary segments shown in Fig. 1. The data source is the daily NCEPNCAR reanalysis and the base period is 1960-2003. Also shown is the net divergence of the vertically integrated moisture flux (div Q), which equals the sum of the outgoing minus the sum of the incoming fluxes.

In summary, the role of the IAS in the seasonal cycle of the moisture budget is to contribute water vapor to the westward transport of moisture from the Atlantic to the Pacific during winter. In contrast, during the summer the IAS is a source of moisture (evaporation exceeds precipitation) during July and a sink during September (Fig. 2). In fact, September is the only month of the year when the IAS is a moisture sink. For all other months, the IAS is a moisture source, with the main source region located in the Caribbean Sea during winter and in the Gulf of Mexico during summer (Peixoto and Oort 1992, their Fig. 12.15; Mestas-Nuñez et al. 2005). On average during the 5-month period JuneOctober the IAS appears to be neither a source nor a sink.

The large-scale structure of the vertically integrated water vapor fluxes during boreal winter and summer are shown in Fig. 3. The pattern of the moisture flows for both seasons are consistent with the seasonal results inferred from Fig. 2. During boreal winter the moisture flow is mostly zonal and during summer both the zonal and meridional flows are important.

\section{b. Association with rainfall}

Seasonal precipitation over the United States and Mexico is well organized into a winter and a summer regime (Hsu and Wallace 1976). In that region, the seasonal relationship between moisture flow and precipi- 


\section{DJFM}

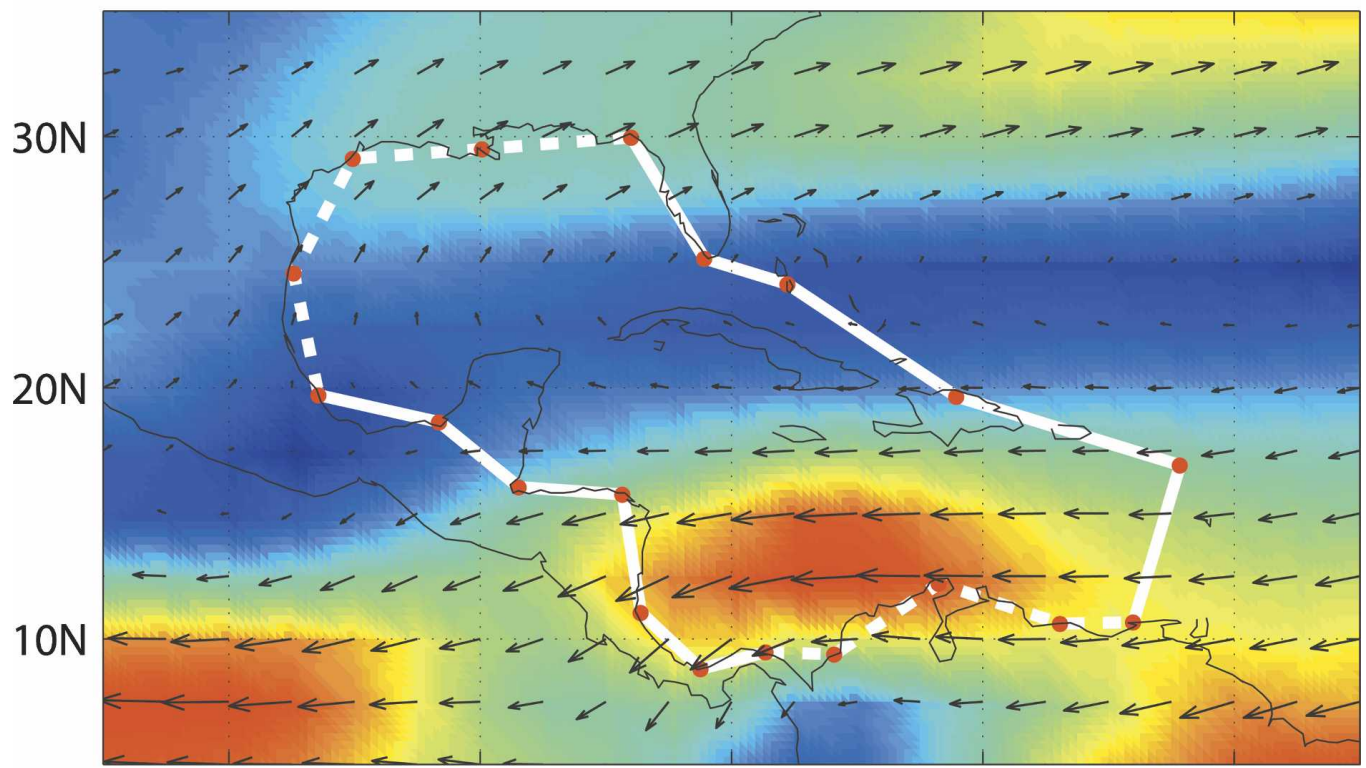

JJAS

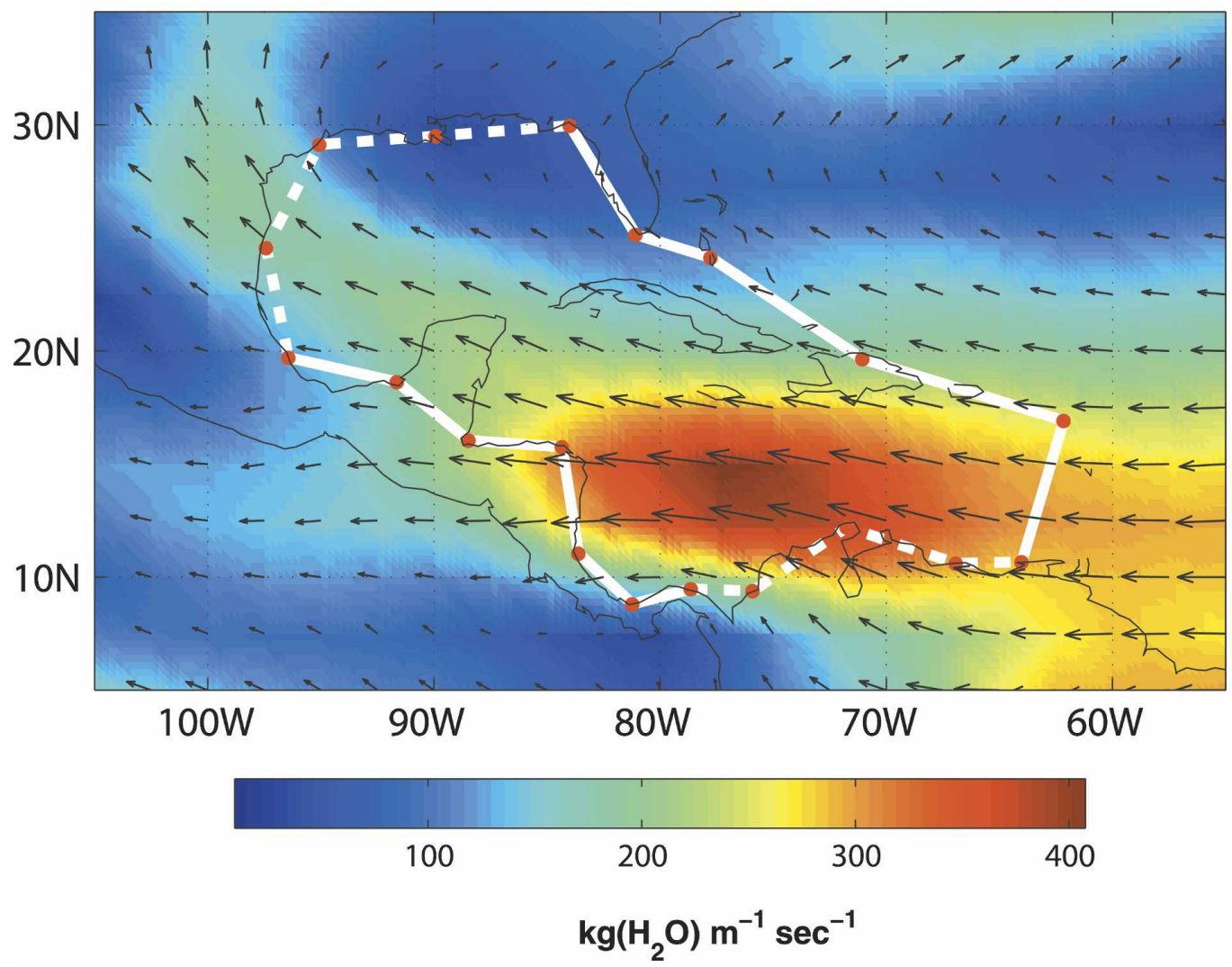

FIG. 3. (top) December-March and (bottom) June-September averages of the monthly vertically integrated water vapor flux vectors calculated from the daily 1960-2003 NCEP-NCAR reanalysis. The magnitudes of the water vapor flux vectors are color contoured. The thick solid (dashed) lines indicate the eastern and western (northern and southern) IAS boundary segments shown in Fig. 1. 
tation has recently been examined with the NCEPNCAR regional reanalysis, satellite estimates, atmospheric soundings, and the operational three-dimensional variational data assimilation (3DVAR) Eta Data Assimilation System (EDAS; Mo et al. 2005). During boreal winter, rainfall covers the Pacific Northwest, California, and the Southeast. The moisture supply mostly comes from the Pacific with the Gulf of Mexico and local evaporation also contributing to the southeast U.S. precipitation.

It is during boreal summer that the moisture fluxes over the IAS play an important role in precipitation over the central United States and Mexico, providing the moisture that feeds the Great Plains LLJ (Higgins et al. 1997), as well as some of the upper-level moisture for the North American monsoon (Adams and Comrie 1997). In general, the IAS moisture fluxes calculated in the present study correlate well with the large-scale features of precipitation over the United States and Mexico during boreal summer. In particular, the meridional moisture flow from South America and into the United States, which shows northward flow increasing from March to July and decreasing more gradually onward (Fig. 2), agrees well with the precipitation cycle over the northern plains and Mexico (Magaña et al. 1999; Mo et al. 2005).

Both the zonal westward moisture flows from the east and to the west have maxima during both summer and winter. This is consistent with the seasonal cycle of the Caribbean LLJ, which has a maximum in February and another in July (Amador et al. 2006), as well as with the seasonal cycle of precipitation over the Pacific Ocean off Central America (Magaña et al. 1999). Note that the strengthening of the Caribbean LLJ during July is consistent with an increase in evaporation, an increase in evaporative cooling, and a decrease in convection that is consistent with the midsummer drought, which is a relative minimum in precipitation over southern Mexico, Central America, and the adjacent oceans during July-August (Magaña et al. 1999; Curtis 2002). As seen in Fig. 2, this drought results in increased moisture divergence in the IAS with a larger export of moisture to the north compared to the import from the south from June to August.

During September, the decrease in IAS moisture divergence that follows the drought conditions is associated with increased precipitation over the Gulf of Mexico and Caribbean. During this period, the inflow of moisture from the south nearly balances the outflow to the north and the moisture convergence results from the larger moisture inflow from the east compared to the outflow to the west.
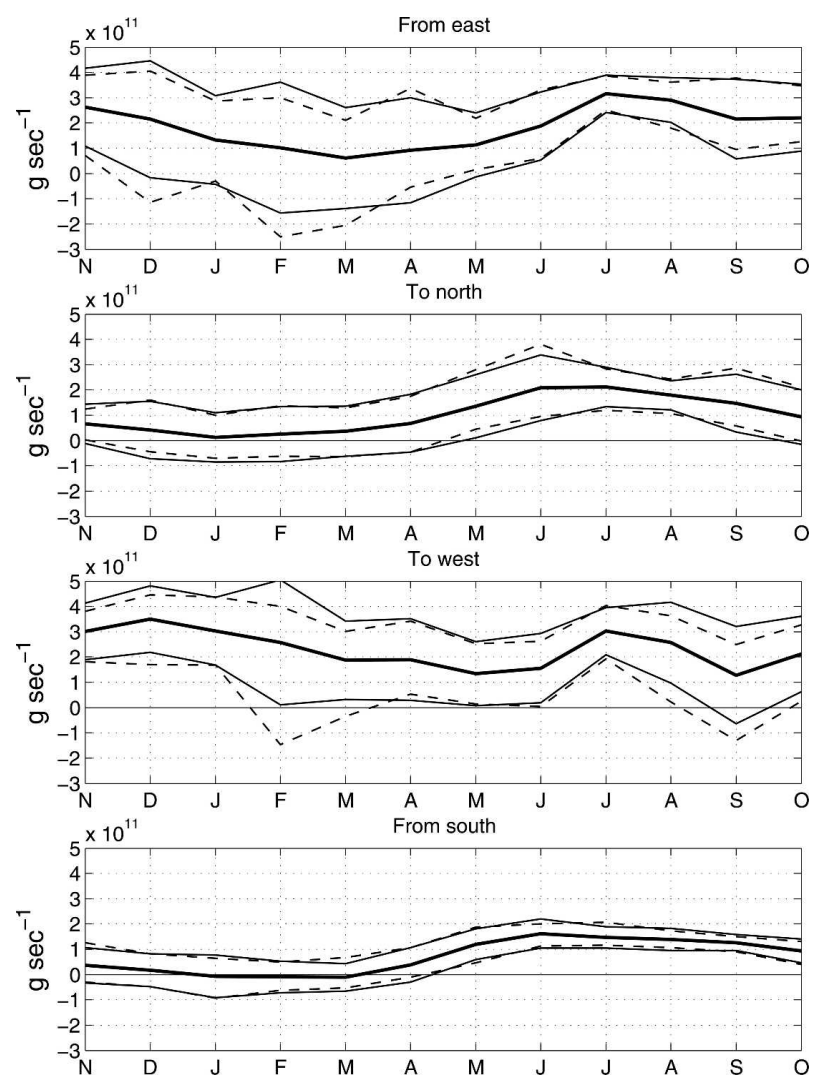

FIG. 4. Long-term mean seasonal cycle of the monthly moisture fluxes through the four IAS boundary segments in Fig. 1 calculated from the daily NCEP-NCAR reanalysis using the 1979-2003 base period. The thin solid lines indicate the \pm 2 std dev range and the thin dashed lines the maximum-minimum range of interannual variability.

\section{Interannual variability}

\section{a. Moisture fluxes}

To study the interannual variability of the moisture fluxes, we use the 1979-2003 base period. The seasonal cycles of the fluxes using this base period are shown in Fig. 4 and are nearly identical to the ones calculated using the longer 1960-2003 base period shown in Fig. 2. In Fig. 4, we also show estimates of the natural range of interannual variability of the flux anomalies with respect to the 1979-2003 flux climatologies. The natural range of interannual variability of the water vapor flux anomalies was defined as the \pm 2 standard deviations range from the mean (thin solid lines in Fig. 4) and in most cases it agrees well with the minimum-maximum range of flux anomaly variability (thin dashed lines in Fig. 4). The range of interannual variability of the zonal fluxes is larger than that of the meridional fluxes. For the zonal fluxes (particularly for the flow from the east) the range of natural variability is larger during the bo- 
TABLE 1. Temporal cross correlations among the monthly anomaly time series of the moisture fluxes from east, to north, to west, and from south, and area-averaged IAS moisture divergence $\{$ div Q $\}$ for 1979-2003. The winter (December-March) and summer (June-September) correlations are shown in the lower-left and upper-right corners, respectively. Significant values of the correlations are set in italics.

\begin{tabular}{lrrrrr}
\hline \hline & $\begin{array}{c}\text { From } \\
\text { east }\end{array}$ & $\begin{array}{c}\text { To } \\
\text { north }\end{array}$ & $\begin{array}{c}\text { To } \\
\text { west }\end{array}$ & $\begin{array}{c}\text { From } \\
\text { south }\end{array}$ & $\{$ div Q $\}$ \\
\hline From east & & 0.71 & 0.48 & -0.08 & 0.32 \\
To north & 0.77 & & -0.11 & 0.03 & -0.03 \\
To west & 0.81 & 0.38 & & 0.19 & 0.85 \\
From south & -0.39 & -0.04 & -0.36 & & -0.03 \\
$\{$ div Q & 0.32 & 0.06 & 0.68 & -0.56 & \\
\hline
\end{tabular}

real winter (about $4 \times 10^{11} \mathrm{~g} \mathrm{~s}^{-1}$ ) than during the boreal summer (about $2 \times 10^{11} \mathrm{~g} \mathrm{~s}^{-1}$ ). For the meridional fluxes the interannual variability range is nearly constant year round and is about twice as large for the flow to the north $\left(2 \times 10^{11} \mathrm{~g} \mathrm{~s}^{-1}\right)$ as it is for the flow from the south $\left(1 \times 10^{11} \mathrm{~g} \mathrm{~s}^{-1}\right)$.

A summary of the temporal correlations of the flux anomalies with each other and with the IAS net moisture divergence for winter and summer is given in the lower-left and upper-right corners of Table 1. Correlations that are significant as explained in section $2 \mathrm{~d}$ are set in italics. During both seasons the inflow from the east (from the Atlantic) is positively correlated to the flow to the west (into the Pacific and Central America) as well as to the flow to the north (into the United States) and to the IAS area-averaged moisture divergence. During boreal winter, the flow from the east is also negatively correlated to the flow from the south, but this does not hold during summer. Furthermore, during this season the flow from the south is negatively correlated to the flow to the west and to the areaaveraged moisture divergence, which is consistent with the negative correlation between the flows from the south and from the east, but the flow from the south it is not related to the flow to the north. In addition, the flow to the north is positively correlated to the flow to the west during winter but it is uncorrelated to it during summer.

\section{b. Association with rainfall}

To investigate potential interannual associations between the moisture fluxes and precipitation, we calculate the correlation of the anomalies of the moisture fluxes through the four IAS boundary segments and the CMAP precipitation during boreal winter and summer (Figs. 5 and 8). To investigate the winter and summer mechanisms behind these associations, we correlated

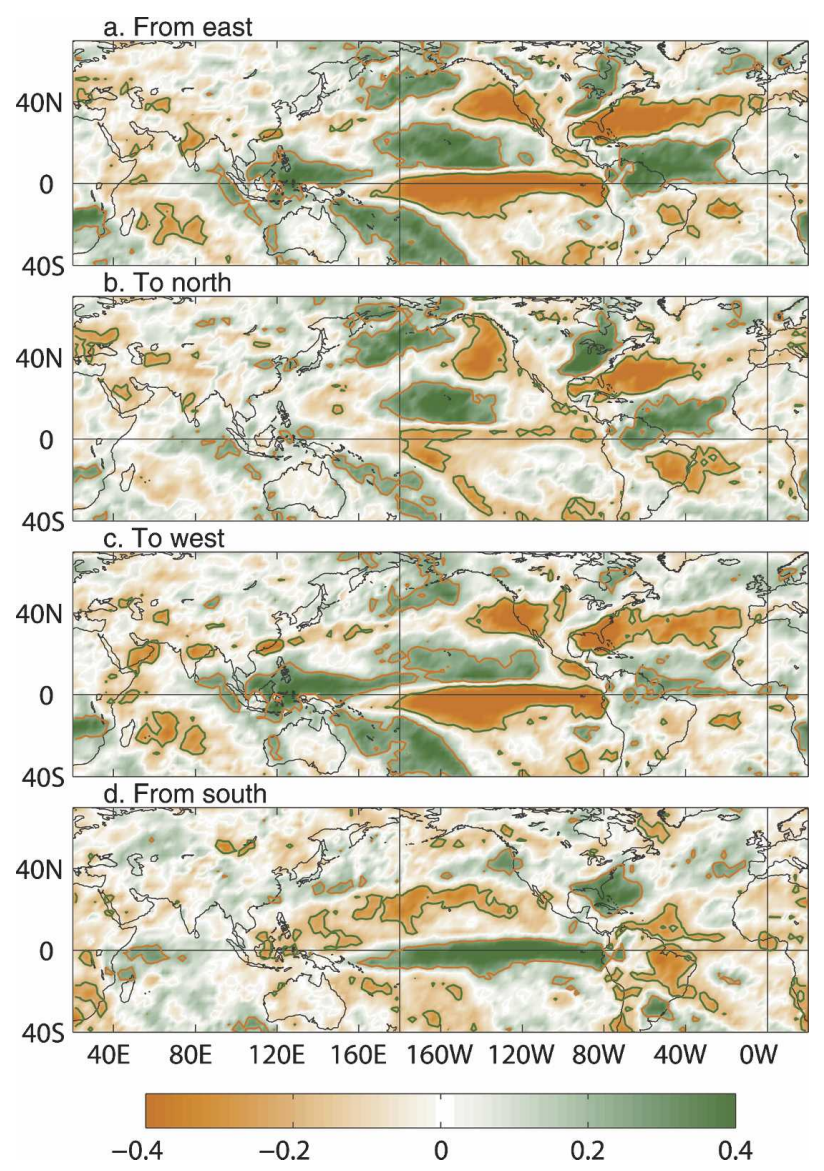

FIG. 5. Correlation of the moisture-flux anomalies through the four IAS boundary segments shown in Fig. 1 with CMAP precipitation for December-March of the period 1979-2003. The base period of the anomalies of both of these variables is also 19792003. The brown (green) contours indicate regions of significant positive (negative) correlation.

these fluxes with global SST (Figs. 6 and 9) as well as with the climatic indices listed in section 2e (Tables 2 and 3$)$. We also correlated the fluxes with winter and summer moisture-convergence anomaly fields $(-\operatorname{div} \mathbf{Q}$, Figs. 7 and 10) from the NCEP-NCAR global reanalysis to identify the relevant moisture sources and sinks.

Overall, during the winter the local and Northern Hemisphere midlatitude patterns of correlations of the fluxes with precipitation (Fig. 5) are similar for the flows from the east, to north, and to west, and similar but opposite for the flow from south, as expected from the correlations between the fluxes summarized in Table 1. The same is true for the patterns of correlations with SST (Fig. 6). The rainfall correlation patterns that are significant over the central United States correspond to the moisture flows from east and to north (Figs. 5a and 5b), which show positive correlations over the east-central United States and two areas of negative 

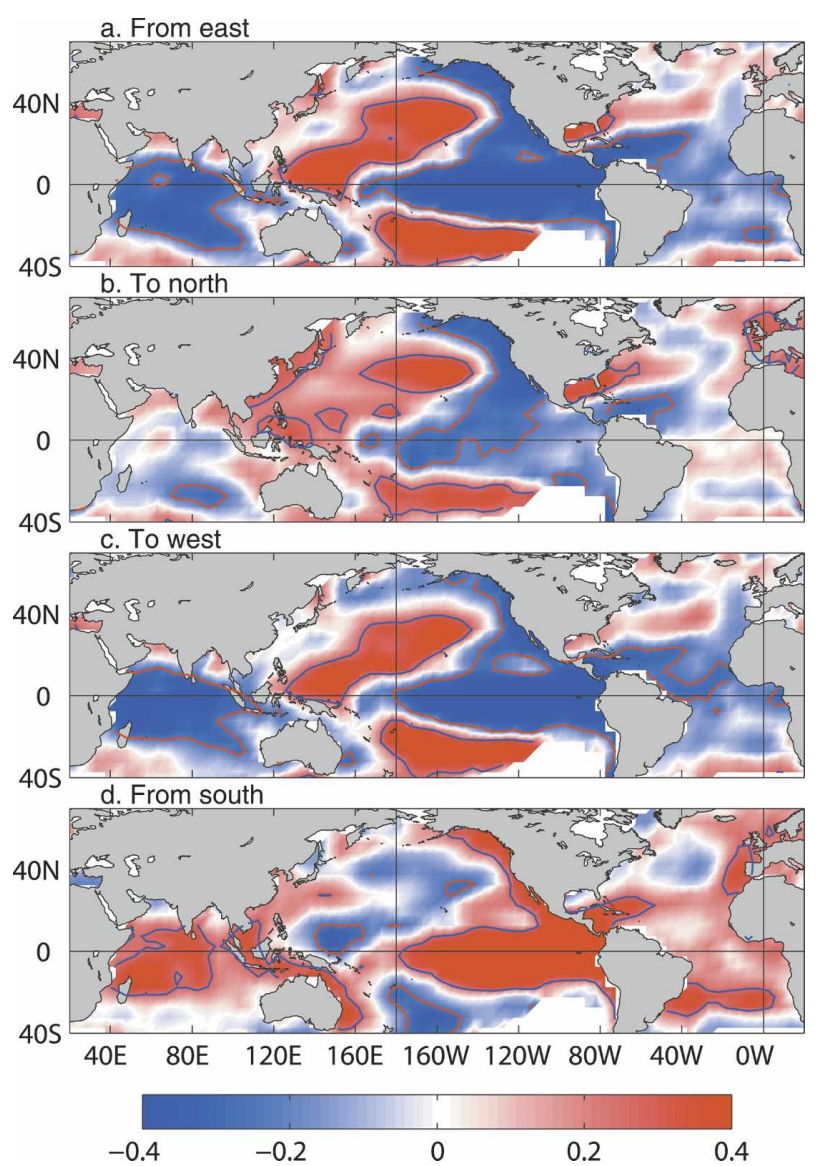

FIG. 6. Correlation of moisture-flux anomalies through the four IAS boundary segments shown in Fig. 1 with SST anomalies for December-March of the period 1979-2003. The base period of the anomalies of both of these variables is also 1979-2003. The blue (red) contours indicate regions of significant positive (negative) correlation.

correlations over the ocean near both coastlines of the North American continent. The SST correlation patterns show a warm Gulf of Mexico-cold Caribbean dipole structure associated with an increase in these fluxes (Figs. 6a and 6b, Table 2). This pattern resembles the PNA teleconnection pattern. This is most noticeable in the midlatitude pattern of SST for the flows from east and to north (Figs. 6a and 6b), which corresponds well with the PNA winter SST pattern (Nigam 2003, his Fig. 2c), and by the correlations of these fluxes with the PNA index (about -0.7 ; see Table 2). Because both of these fluxes are inversely correlated to the PNA, the precipitation and SST patterns just discussed correspond to an increase in the fluxes and a decrease in the PNA index. The source of the moisture for these associations seems to be the Gulf of Mexico and the region of the North Atlantic just east of the Bahamas Islands (Figs. $7 \mathrm{a}$ and $7 \mathrm{~b}$ ).
TABLE 2. Temporal correlations of monthly moisture flux anomalies through the four IAS boundary segments and $\{\operatorname{div} \mathbf{Q}\}$ with the PNA, Niño-3, Niño-3.4, NAO, tropical north Atlantic temperature (TNA), IAS temperature, Gulf of Mexico temperature, Caribbean temperature, and WHWP indices for DecemberMarch. Significant correlations at the $95 \%$ level are set in italics.

\begin{tabular}{lcrrrr}
\hline \hline & $\begin{array}{c}\text { From } \\
\text { east }\end{array}$ & $\begin{array}{c}\text { To } \\
\text { north }\end{array}$ & $\begin{array}{c}\text { To } \\
\text { west }\end{array}$ & $\begin{array}{c}\text { From } \\
\text { south }\end{array}$ & $\{$ div Q $\}$ \\
\hline PNA & -0.67 & -0.69 & -0.42 & 0.24 & -0.16 \\
Niño-3 & -0.59 & -0.22 & -0.57 & 0.53 & -0.30 \\
Niño-3.4 & -0.59 & -0.27 & -0.54 & 0.46 & -0.27 \\
NAO & 0.32 & 0.24 & 0.30 & -0.06 & 0.12 \\
TNA & -0.22 & -0.12 & -0.26 & 0.14 & -0.22 \\
IAS temp & -0.05 & 0.11 & -0.21 & 0.34 & -0.41 \\
Gulf temp & 0.34 & 0.34 & 0.16 & -0.02 & -0.10 \\
Caribbean temp & -0.37 & -0.18 & -0.40 & 0.42 & -0.39 \\
WHWP & -0.56 & -0.17 & -0.64 & 0.50 & -0.46 \\
\hline
\end{tabular}

At low latitudes during boreal winter, an ENSO signal is identified in the correlation of the flows from east, to west, and from south with the Niño-3 and -3.4 indices (Table 2) and in the SST patterns associated with these fluxes (Figs. 6a, 6c, and 6d), which are similar to the canonical ENSO SST pattern (e.g., Mestas-Nuñez and Enfield 2001). In the Tropics, the precipitation patterns associated with the flow from east (Fig. 5a) to west (Fig. 5c) (from south; Fig. 5d) show negative (positive) precipitation anomalies over the central and eastern tropical Pacific and positive (negative) precipitation anomalies over the western tropical North Atlantic and northern South America, which corresponds well with the ENSO pattern in midtropospheric vertical velocity (Mestas-Nuñez and Enfield 2001). The associated SST patterns in Figs. 6a and 6c (Fig. 6d) show a colder (warmer) central and eastern tropical Pacific associated with an increase in the flow from east/to west (from south). The moisture convergence pattern associated with the ENSO signal is seen in Figs. 7a, 7c, and 7d. There we see that during the positive ENSO phase (El Niño) the flow from the east and to the west decreases

TABle 3. As in Table 2 but for June-September.

\begin{tabular}{lrrrrr}
\hline & $\begin{array}{c}\text { From } \\
\text { east }\end{array}$ & $\begin{array}{c}\text { To } \\
\text { north }\end{array}$ & $\begin{array}{c}\text { To } \\
\text { west }\end{array}$ & $\begin{array}{c}\text { From } \\
\text { south }\end{array}$ & $\{$ div Q $\}$ \\
\hline PNA & -0.55 & -0.47 & -0.23 & -0.002 & -0.17 \\
Niño-3 & -0.07 & -0.12 & 0.31 & 0.45 & 0.27 \\
Niño-3.4 & -0.05 & -0.13 & 0.36 & 0.42 & -0.34 \\
NAO & 0.03 & -0.07 & 0.08 & 0.06 & -0.01 \\
TNA & -0.16 & -0.09 & -0.22 & 0.02 & -0.27 \\
IAS temp & -0.19 & -0.16 & -0.01 & 0.31 & -0.10 \\
Gulf temp & 0.02 & -0.03 & 0.16 & 0.36 & 0.08 \\
Caribbean temp & -0.26 & -0.20 & -0.11 & 0.22 & -0.19 \\
WHWP & -0.17 & -0.16 & 0.06 & 0.20 & 0.05 \\
\hline
\end{tabular}




\section{a. From east}

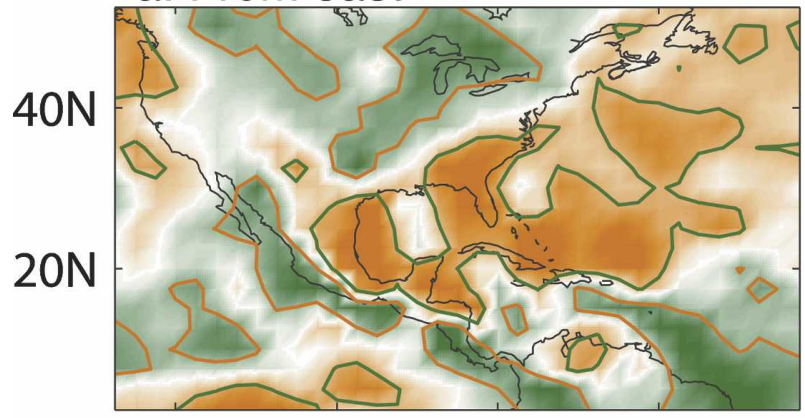

b. To north

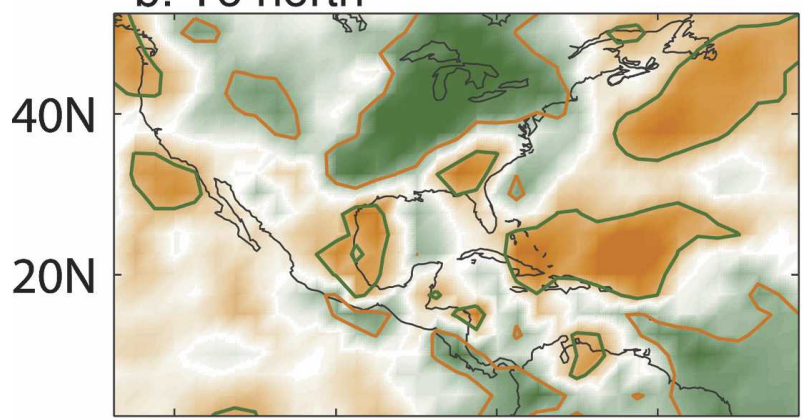

c. To west
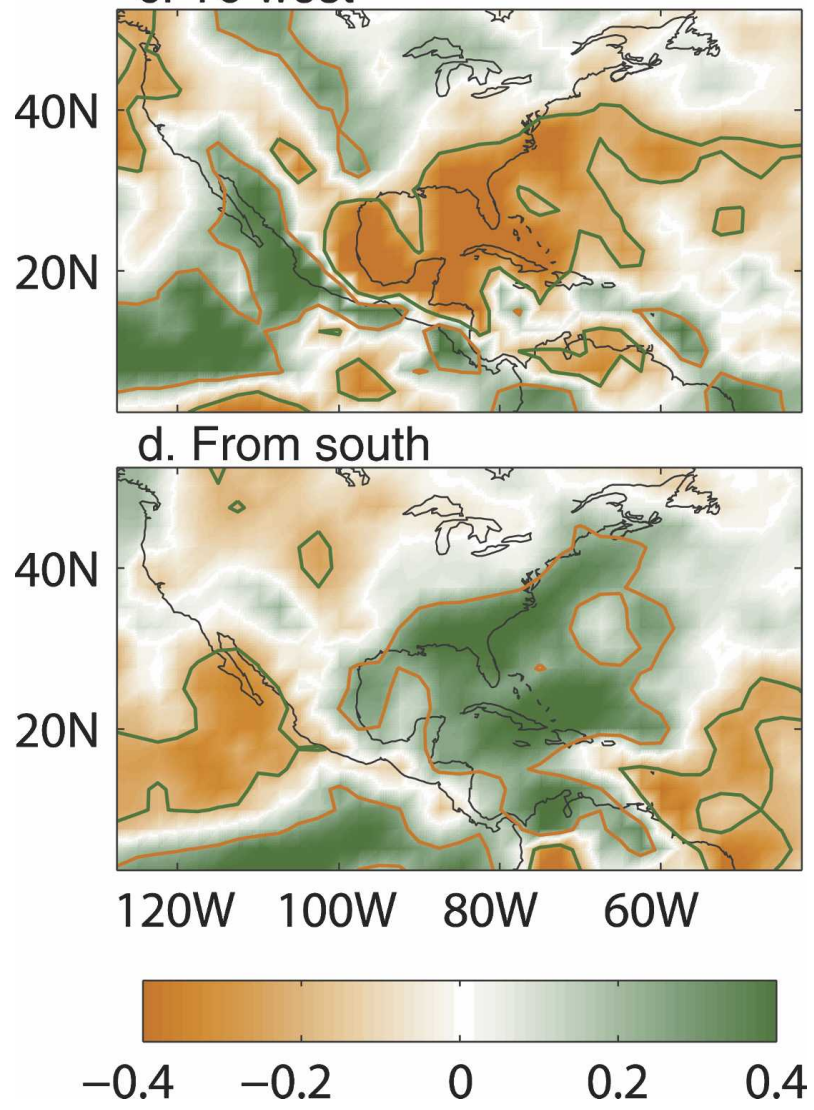

and the flow from the south increases. This decreases the export of moisture from the Atlantic to the Pacific, increases precipitation and convergence over the IAS and the region of the North Atlantic just east of the Bahamas Islands, and decreases convergence over central North America and northern South America. The decrease of the flow from the east and to the west is consistent with the cyclonic wind and sea level pressure anomalies in the western midlatitude North Atlantic and in the IAS and westerly Northern Hemisphere trade wind anomalies that are present during warm ENSO events (Enfield and Mayer 1997). The associations with the flow from the south are similar but opposite to the relationship with the flow from the east because these flows are inversely correlated with the ENSO indices (Table 2).

In addition to the winter PNA and ENSO associations with the IAS moisture fluxes described above, there also seems to be an NAO association. Table 2 shows that the NAO index is positively correlated to the flows from east, to north, and to west but these values (about 0.2 to 0.3 ) are weaker than the PNA and ENSO correlations (about -0.6 to -0.7 ).

During boreal summer, the patterns of precipitation correlations (Fig. 8) for the flows from east and to north show positive regions in the east-central United States and negative values over the eastern and western U.S. coastlines, as was the case for winter. These fluxes are significantly correlated to the summer values of the PNA index but not to the ENSO or NAO indices. The SST patterns (Fig. 9) and Table 3 show significant correlations over the Caribbean. The $-\operatorname{div} \mathbf{Q}$ patterns show that the moisture source regions are the Gulf of Mexico and the area just east of the Bahamas Islands and the sink the region in the east-central United States similar to the winter situation. The temperature of the Gulf of Mexico does not seem to play a role for moisture transport into the United States (flows from the east and to the north) during summer.

The boreal summer variations of the other two fluxes, to the west and from the south, dominate the lower-latitude correlations patterns. For instance, an increase in these fluxes is associated with an increase of

$\leftarrow$

FIG. 7. Correlation of the moisture-flux anomalies through the four IAS boundary segments shown in Fig. 1 with anomalies of the convergence of the vertically integrated water vapor flux ( $-\operatorname{div} \mathbf{Q})$ for December-March of the period 1979-2003. The base period of the anomalies of both of these variables is also 19792003. The brown (green) contours indicate regions of significant positive (negative) correlation. 

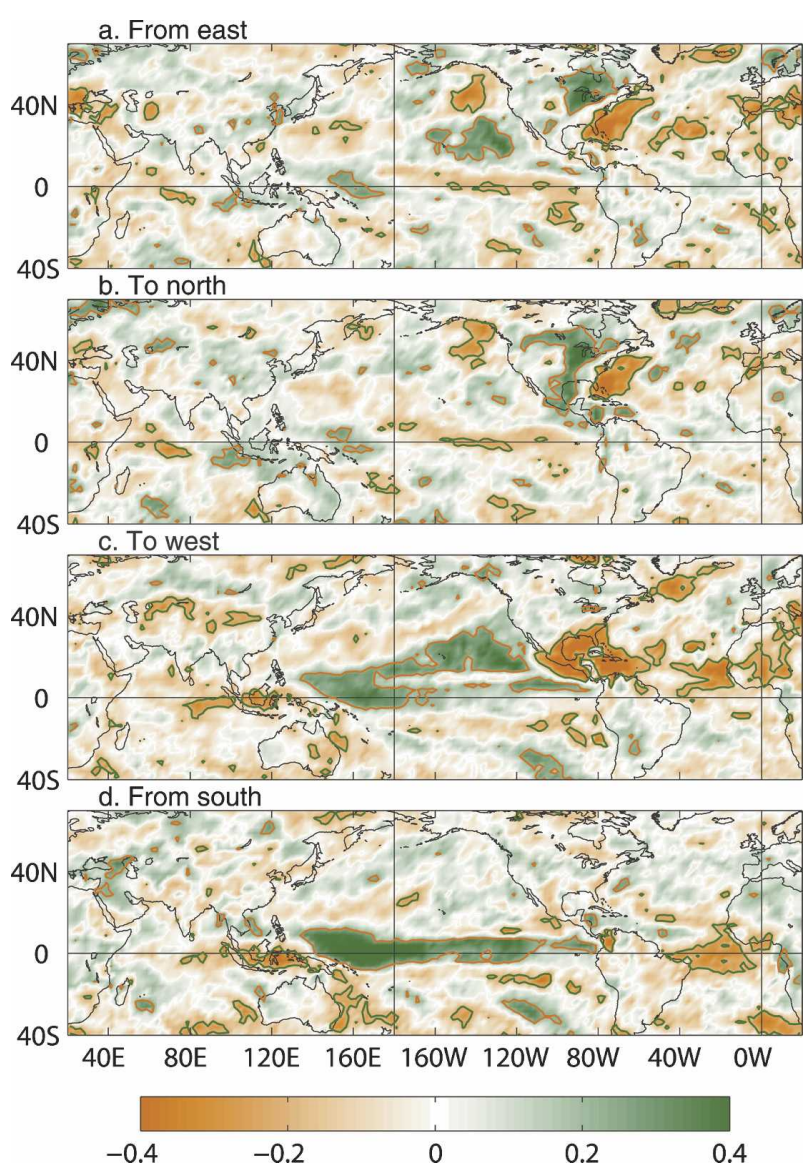

FIG. 8. As in Fig. 5 but for June-September.

precipitation over the Pacific and a decrease over the IAS and the tropical Atlantic (Figs. 8c and 8d). The SST patterns (Figs. 9c and 9d) and Table 3 show that this is related to El Niño warming over the central and eastern tropical Pacific but accompanied by cooling over the tropical Atlantic. The $-\operatorname{div} \mathbf{Q}$ patterns (Fig. 10) indicate that during El Niño summers there is an increase of moisture convergence over the Pacific and a decrease over the IAS and northern South America (Figs. 10c and 10d) consistent with the corresponding precipitation patterns in Fig. 8.

\section{Summary and conclusions}

We have estimated the seasonal and interannual variabilities of the moisture fluxes through the eastern, northern, western, and southern boundaries of the IAS using the NCEP-NCAR reanalysis fields. We used correlation analysis to explore potential associations of these fluxes with precipitation, SST, various climatic indices, and moisture convergence fields for the 19792003 period. Our main results are listed below.
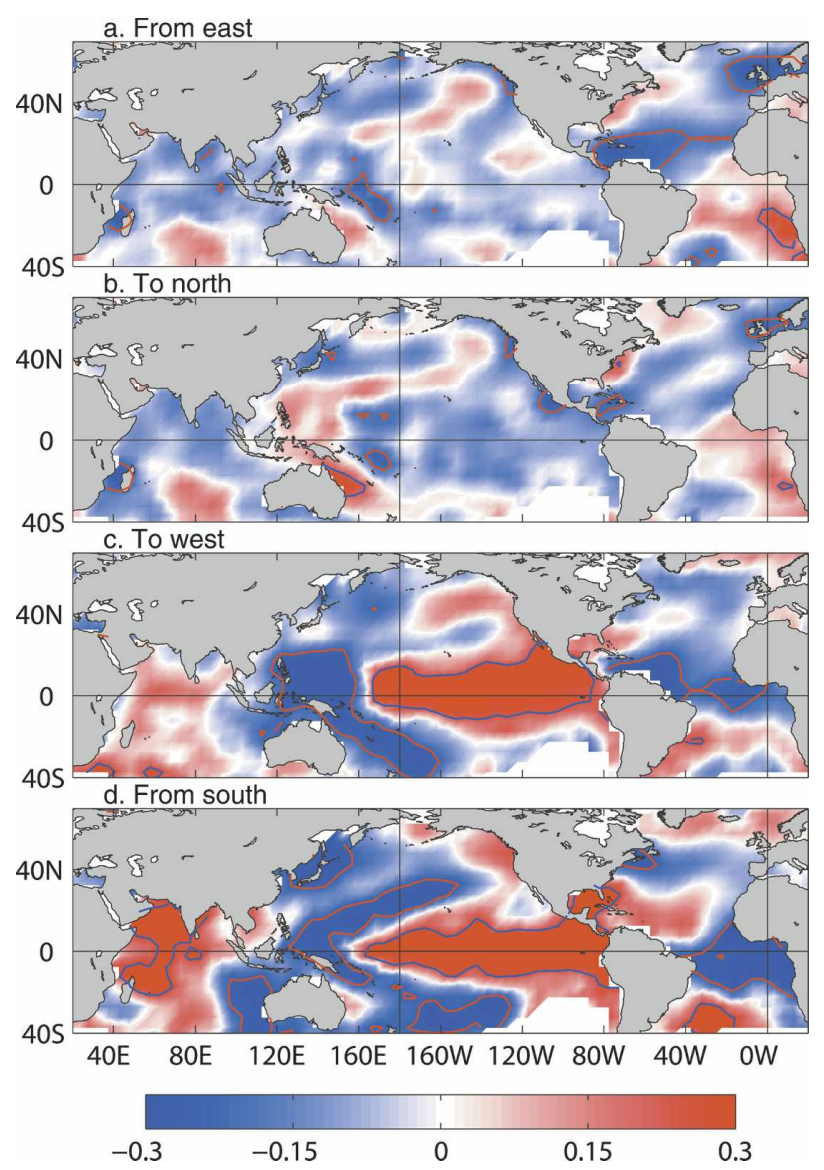

FIG. 9. As in Fig. 6 but for June-September.

For the seasonal cycle we have shown the following.

The seasonal changes in the moisture fluxes could be divided into summer and winter regimes, as is also the case for precipitation and moisture divergence.

In boreal winter, the moisture-flux balance over the IAS is mostly zonal with moisture imported from the tropical North Atlantic and evaporated locally over the IAS balancing the transport toward the Pacific over Mexico and Central America.

In boreal summer, the balance is mainly between moisture imported from the tropical Atlantic and South America and moisture exported both to the Pacific and into the North American heartland. Although relatively smaller, the IAS represents a source during July and a sink during September.

The meridional flows of moisture increase from March to July and decrease onward (Fig. 2) and are accompanied with similar changes in precipitation over the northern plains and Mexico. The zonal flows of moisture have peaks during both summer and winter that are consistent with the seasonal cycle of the Caribbean LLJ. 


\section{a. From east}

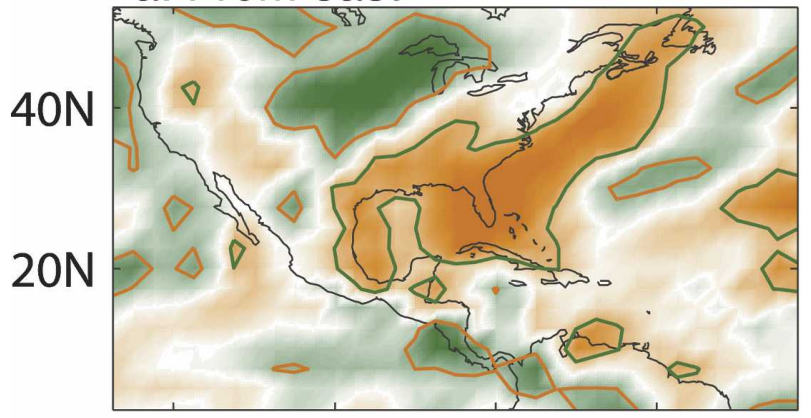

b. To north

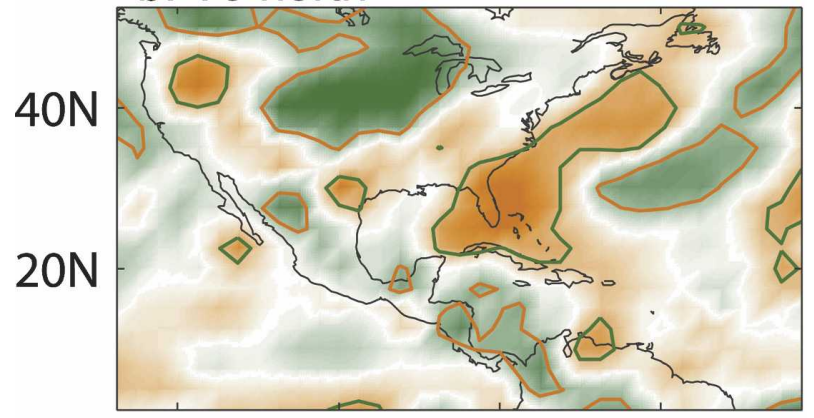

c. To west
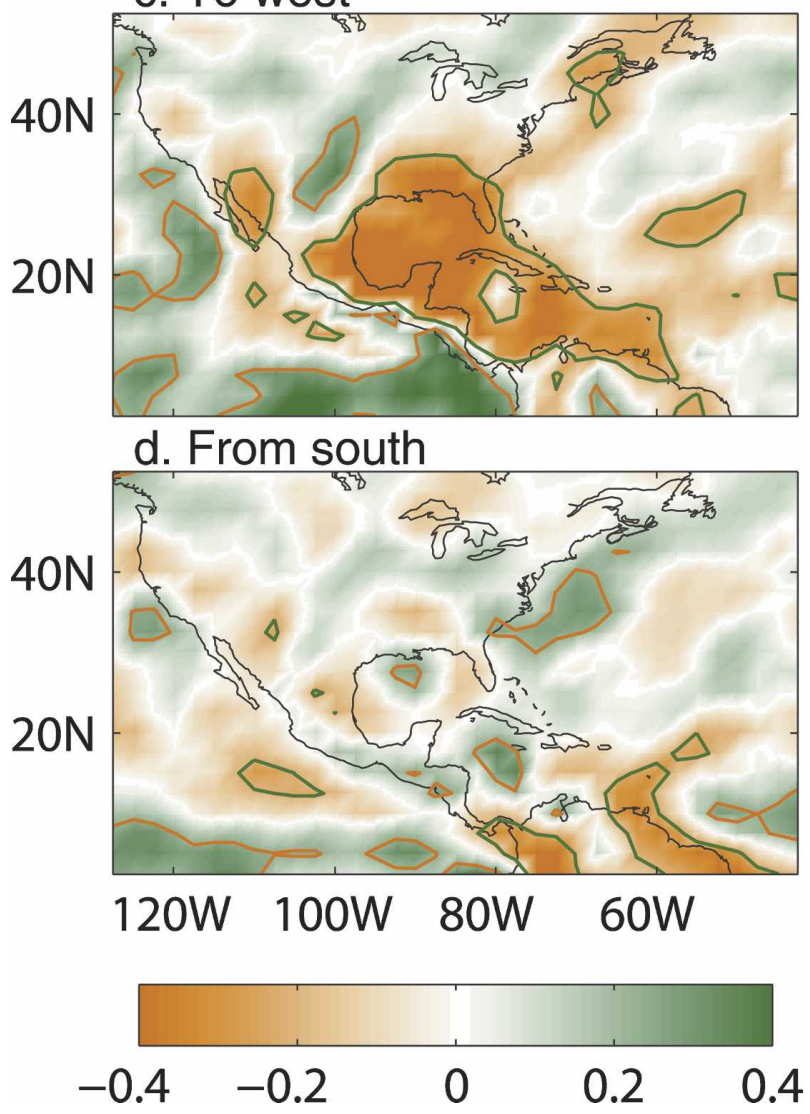

FIg. 10. As in Fig. 7 but for June-September.
During July, there is an increase in the Caribbean LLJ, an increase in evaporation, and a decrease in convection in the IAS, which is consistent with midsummer drought conditions over the region.

The following are our findings for the interannual time scales.

During the boreal winter, the main climatic signals correlated with the moisture flows over the IAS are the PNA pattern and ENSO. However, there is also a weak correlation with the NAO.

The boreal winter PNA signal involves mainly the moisture fluxes from the east and to the north. A decrease in the PNA is associated with an increase in the moisture inflow from the east, an increase in the outflow to the north, and an increase in precipitation and moisture convergence over the eastcentral United States. The water vapor source regions are the Gulf of Mexico and the North Atlantic region just east of the Bahamas Islands. A decrease of the PNA is also associated with an increase (decrease) of the flow to the west (from the south).

The boreal winter ENSO signal involves mainly the moisture flows through the eastern, western, and southern boundaries. During El Niño there is a decrease of the moisture flow from the east (i.e., the Caribbean LLJ) and to the west, and an increase of the flow from the south and of convergence and precipitation over the IAS, especially over the Gulf of Mexico. The decrease of the Caribbean LLJ during El Niño boreal winters is consistent with previous studies using the Eta Model (Vernekar et al. 2003).

During boreal summer, the only relevant climatic signals are the PNA pattern and ENSO.

The PNA summer signal is similar to the winter counterpart (except the flow through the southern boundary is not involved) and is the main mechanism associated with the summer moisture inflow into the United States. Note that Ruiz-Barradas and Nigam (2005) have also invoked the PNA to explain the summer rainfall variability in global atmospheric reanalysis over the U.S. Great Plains.

The ENSO summer signal involves only the IAS moisture fluxes to the west and from the south and not the moisture flux to the north into the United States. During El Niño summers, there is an increase of the moisture inflow from the south, an increase in the outflow to the west into the tropical Pacific, and a decrease of convergence and precipitation over the IAS and the tropical Atlantic. 


\section{Concluding remarks}

The current study utilizes the NCEP-NCAR global reanalysis following Mestas-Nuñez et al. (2005), who verified the usefulness of this dataset for moisture transport studies in the IAS region. However, the results presented here should be compared to moisture transports estimated from other available multiyear datasets such as the NCEP-Department of Energy (DOE) reanalysis (sometimes referred to as Reanalysis 2; Kanamitsu et al. 2002) or the ECMWF 40-yr reanalysis (ERA-40; Uppala et al. 2005).

The absence during summer of an ENSO association with the moisture inflow from the IAS into the United States is consistent with the lack of association between summer rainfall in the central United States and ENSO since 1979 (Hu and Feng 2001b). However, the strength of ENSO as well as other teleconnection patterns varies over decadal and multidecadal time scales (e.g., Gershunov and Barnett 1998; Enfield et al. 2001). Thus, our results only pertain to the 1979-2003 period. During other epochs the summer ENSO teleconnections to the hydroclimate of the central United States may be significant (Hu and Feng 2001b).

The importance of the interannual variability of the southerly transport of moisture from the Gulf of Mexico and its association with summer precipitation in the central United States has been noted by other authors (Mo et al. 1995; Paegle et al. 1996; Hu and Feng 2001a). Here, we go further to propose that these associations also involve variations in the Caribbean LLJ and the PNA pattern and that the source of moisture is the Gulf of Mexico and the North Atlantic region just east of the Bahamas Islands.

Acknowledgments. We are thankful to the NOAA CIRES Climate Diagnostics Center for providing the NCEP-NCAR reanalysis dataset online (www.cdc. noaa.gov), Jay Harris for data preparation, and two anonymous reviewers for helpful comments. Financial support was provided by grants from the National Oceanic and Atmospheric Administration (NOAA, through PACS and GAPP). This research was carried out in part under the auspices of the Cooperative Institute for Marine and Atmospheric Studies (CIMAS), a joint institute of the University of Miami and NOAA, Cooperative Agreement NA17RJ1226. The findings and conclusions in this report are those of the authors and do not necessarily represent the views of the funding agency.

\section{REFERENCES}

Adams, D. K., and A. C. Comrie, 1997: The North American monsoon. Bull. Amer. Meteor. Soc., 78, 2197-2213.
Amador, J. A., 1998: A climatic feature of the tropical Americas: The trade wind easterly jet. Tóp. Meteor. Oceanogr., 5, 91102.

_ , and V. Magaña, 1999: Dynamics of the low-level jet over the Caribbean Sea. Preprints, 23d Conf. on Hurricanes and Tropical Meteorology, Dallas, TX, Amer. Meteor. Soc., 868869.

_ E. J. Alfaro, O. G. Lizano, and V. O. Magaña, 2006: Atmospheric forcing of the eastern tropical Pacific: A review. Progress in Oceanography, Vol. 69, Pergamon Press, 101-142.

Barnston, A. G., and R. E. Livezey, 1987: Classification, seasonality and persistence of low-frequency atmospheric circulation patterns. Mon. Wea. Rev., 115, 1083-1126.

Black, T. L., 1994: The new NMC mesoscale Eta Model: Description and forecast examples. Wea. Forecasting, 9, 265-278.

Bottomley, M., C. K. Folland, J. Hsiung, R. E. Newell, and D. E. Parker, 1990: Global Ocean Surface Temperature Atlas (GOSTA). Her Majesty's Stationery Office, 20 pp. +313 plates.

Curtis, S., 2002: Interannual variability of the bimodal distribution of summertime rainfall over Central America and tropical storm activity in the far-eastern Pacific. Climate Res., 22, 141146.

Davis, R. E., 1976: Predictability of sea surface temperature and sea level pressure anomalies over the North Pacific Ocean. $J$. Phys. Oceanogr., 6, 249-266.

Enfield, D. B., and D. A. Mayer, 1997: Tropical Atlantic sea surface temperature variability and its relation to El NiñoSouthern Oscillation. J. Geophys. Res., 102, 929-945.

_ A. M. Mestas-Nuñez, D. A. Mayer, and L. Cid-Serrano, 1999: How ubiquitous is the dipole relationship in tropical Atlantic sea surface temperatures? J. Geophys. Res., 104, 7841-7848.

_ - , and P. J. Trimble, 2001: The Atlantic multidecadal oscillation and its relation to rainfall and river flows in the continental U.S. Geophys. Res. Lett., 28, 2077-2080.

Gershunov, A., and T. P. Barnett, 1998: Interdecadal modulations of ENSO teleconnections. Bull. Amer. Meteor. Soc., 79, 27152725 .

Gibson, J. K., P. Kallberg, S. Uppala, A. Hernandez, A. Nomura, and E. Serrano, 1997: Era description. ECMWF Re-Analysis (ERA) Project Rep. Series 1, 72 pp.

Hastenrath, S. L., 1966: The flux of atmospheric water vapor over the Caribbean Sea and the Gulf of Mexico. J. Appl. Meteor., $\mathbf{5 , 7 7 8 - 7 8 8 . ~}$

Higgins, R. W., Y. Yao, E. S. Yarosh, J. E. Janowiak, and K. C. Mo, 1997: Influence of the Great Plains low-level jet on summertime precipitation and moisture transport over the central United States. J. Climate, 10, 481-507.

Hsu, C. F., and J. M. Wallace, 1976: The global distribution of the annual and semiannual cycles in precipitation. Mon. Wea. Rev., 104, 1093-1101.

Hu, Q., and S. Feng, 2001a: Climatic role of the southerly flow from the Gulf of Mexico in interannual variations in summer rainfall in the central United States. J. Climate, 14, 3156-3170.

- and — 2001b: Variations of teleconnection of ENSO and interannual variation in summer rainfall in the central United States. J. Climate, 14, 2469-2480.

Hurrell, J. W., 1995: Decadal trends in the North Atlantic Oscillation, 1995: Regional temperatures and precipitation. Science, 269, 676-679.

Kalnay, E., and Coauthors, 1996: The NCEP/NCAR 40-Year Reanalysis Project. Bull. Amer. Meteor. Soc., 77, 437-471. 
Kanamitsu, M., W. Ebisuzaki, J. Woollen, S. K. Yang, J. J. Hnilo, M. Fiorino, and G. L. Potter, 2002: NCEP-DOE AMIP-II reanalysis (R-2). Bull. Amer. Meteor. Soc., 83, 1631-1643.

Kaplan, A., M. A. Cane, Y. Kushnir, A. C. Clement, M. B. Blumenthal, and B. Rajagopalan, 1998: Analysis of global sea surface temperatures 1856-1991. J. Geophys. Res., 103, 18 567-18 589.

Kistler, R., and Coauthors, 2001: The NCEP-NCAR 50-Year Reanalysis: Monthly means CD-ROM and documentation. Bull. Amer. Meteor. Soc., 82, 247-267.

Magaña, V., J. A. Amador, and S. Medina, 1999: The midsummer drought over Mexico and Central America. J. Climate, 12, $1577-1588$.

Mestas-Nuñez, A. M., and D. B. Enfield, 2001: Eastern equatorial Pacific SST variability: ENSO and non-ENSO components and their climatic associations. J. Climate, 14, 391-402.

—, C. Zhang, and D. B. Enfield, 2005: Uncertainties in estimating moisture fluxes over the Intra-Americas Sea. J. Hydrometeor., 6, 696-709.

Mo, K. C., J. Nogues-Paegle, and J. Paegle, 1995: Physical mechanisms of the 1993 summer floods. J. Atmos. Sci., 52, 879-895.

—, M. Chelliah, M. L. Carrera, R. W. Higgins, and W. Ebisuzaki, 2005: Atmospheric moisture transport over the United States and Mexico as evaluated in the NCEP regional reanalysis. J. Hydrometeor., 6, 710-728.

Mora, I., and J. A. Amador, 2000: El ENOS, el IOS y la corriente en chorro de bajo nivel en el oeste del Caribe. Tóp. Meteor. Oceanogr., 7, 1-20.

Nigam, S., 2003: Teleconnections. Encyclopedia of Atmospheric
Sciences, J. R. Holton, J. A. Pyle, and J. A. Curry, Eds. Elsevier Science, 2243-2269.

Paegle, J., K. C. Mo, and J. Nogues-Paegle, 1996: Dependence of simulated precipitation on surface evaporation during the 1993 United States summer floods. Mon. Wea. Rev., 124, 345361.

Peixoto, J. P., and A. H. Oort, 1992: Physics of Climate. American Institute of Physics, 520 pp.

Reynolds, R. W., and T. M. Smith, 1994: Improved global sea surface temperature analysis using optimum interpolation. $J$. Climate, 7, 929-948.

Ruiz-Barradas, A., and S. Nigam, 2005: Warm season rainfall variability over the U.S. Great Plains in observations, NCEP and ERA-40 reanalyses, and NCAR and NASA atmospheric model simulations. J. Climate, 18, 1808-1830.

Uppala, S. M., and Coauthors, 2005: The ERA-40 re-analysis. Quart. J. Roy. Meteor. Soc., 131, 2961-3012.

Vernekar, A. D., B. P. Kirtman, and M. J. Fennessy, 2003: Lowlevel jets and their effects on the South American summer climate as simulated by the NCEP Eta Model. J. Climate, 16, 297-311.

Wallace, J. M., and D. S. Gutzler, 1981: Teleconnections in the geopotential height field during the Northern Hemisphere winter. Mon. Wea. Rev., 109, 784-812.

Wang, C., and D. B. Enfield, 2001: The tropical Western Hemisphere warm pool. Geophys. Res. Lett., 28, 1635-1638.

Xie, P., and P. A. Arkin, 1997: Global precipitation: A 17-year monthly analysis based on gauge observations, satellite estimates, and numerical model outputs. Bull. Amer. Meteor. Soc., 78, 2539-2558. 